\title{
Ocular myiasis caused by Chrysomya bezziana - a case report
}

\author{
This article was published in the following Dove Press journal: \\ Clinical Ophthalmology \\ 3 March 2015 \\ Number of times this article has been viewed
}

\author{
Amit S Nene \\ Anoop Mishra \\ Purnima Dhand \\ Department of Ophthalmology, \\ Assam Medical College and Hospital, \\ Dibrugarh, Assam, India
}

\begin{abstract}
Ophthalmomyiasis can have variable presentation depending on the type of fly, structures involved, and level of penetration. A 42-year-old female presented with extensive myiasis of the right eye. A lesion of $3 \times 2 \mathrm{~cm}$ was noted at the medial canthus and was infested with maggots. The larvae were removed meticulously and the wound debrided. The larva isolated was that of Chrysomya bezziana (Old World screwworm). Computed tomography (CT) scan was normal. The wound was dressed regularly and healed by secondary intention. Ocular myiasis is a rare disease that can lead to life threatening consequences, such as intracranial extension. Prompt management with debridement and radical antibiotic therapy is essential.
\end{abstract}

Keywords: ophthalmomyiasis, medial canthus, screwworm

\section{Introduction}

Involvement of ocular structures by larvae of dipterous flies is widely known as ophthalmomyiasis. Human ophthalmomyiasis was first reported by Keyt in 1900 and later on by Elliot, in $1910 .{ }^{1}$ It is predominantly seen in tropical and subtropical regions in countries with poor hygiene, inadequate living conditions, and warm weather. Myiasis in man is found rarely, and eye involvement in human myiasis is less than $5 \% .^{2}$ The parasites most commonly affecting the eye and orbit are the larva of Hypoderma bovis (hornet fly), Oestrus ovis (sheep botfly), and, rarely, by Chrysomya bezziana. ${ }^{3}$ C. bezziana, also known as Old World screwworm, is an obligate parasite and belongs to the order Diptera, family Calliphyridae, and suborder Cyclorrhpha. As the name suggests, it is distributed throughout much of Africa, the Gulf countries, the Indian subcontinent, and Southeast Asia from People's Republic of China, through the Malay Peninsula and the Indonesian and Philippine islands to Papua New Guinea (Figure 1). ${ }^{4}$

\section{Case report}

A 42-year-old female from Dibrugarh, Assam visited us with history of minor injury to the right eye due to fall into a sewer when in a drunken state. She presented 6 days after the injury with chief complaints of swelling, itching, and blood-stained, foulsmelling discharge from the wound. Her husband also noticed small whitish-yellow worm-like structures crawling out from the wound (Figure 2). She had no significant past history, and systemic examination was normal.

On local examination, best corrected visual acuity of the right eye was $6 / 18$. There was generalized right periorbital edema, with matting of the eyelashes and severe conjunctival vascular engorgement. A lesion of approximately $3 \times 2 \mathrm{~cm}$ was noted at the medial canthus. The ulcer had indurated margins with scanty blood-stained, foulsmelling discharge. Small freely moving maggots were visible in the wound. The cornea
Department of Ophthalmology, Assam Medical College and Hospital, Dibrugarh, Assam, 786002, India

Email amitnene9@gmail.com 


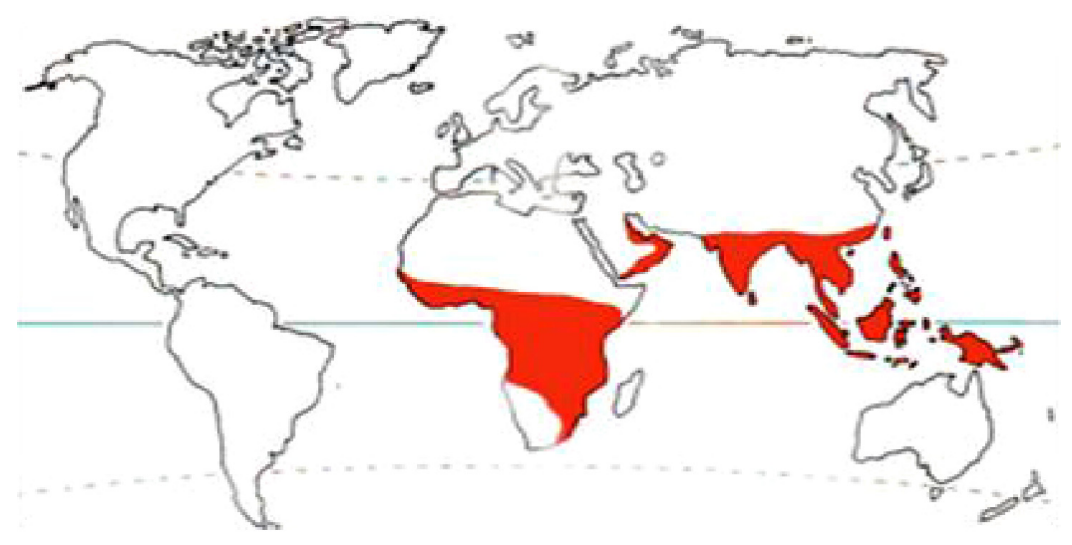

Figure I Showing the distribution of Chrysomya bezziana worldwide.

was hazy, and further detailed examination was not possible. Computed tomography (CT) scan of the orbit showed no signs of bone erosion or paranasal sinus involvement, except for the soft tissue swelling (Figure 3). The other eye was also examined for maggots and was found to be normal.

Turpentine oil packing was done to immobilize the maggots. Mechanical debridement of the wound was done, and freely moving maggots were removed with the help of forceps, under local anesthesia using 4\% xylocaine (Figure 4). Regular dressing of the wound was done, with removal of maggots, for next 4 days. The patient was treated with intravenous amoxicillin sodium/potassium clavulanate $1.2 \mathrm{gm}$ given 8 hourly and ibuprofen $400 \mathrm{mg}$ twice daily for 3 days, followed by oral amoxicillin/clavulanic acid $625 \mathrm{mg}$ twice daily for 5 days. A single dose of albendazole $400 \mathrm{mg}$ tablet was also given. Local application of moxifloxacin $0.5 \%$ ointment to the right eye for 1 week was advised. The wound started to heal, with granulation tissue formation, and healing was completed by the end of 2 weeks (Figure 5).

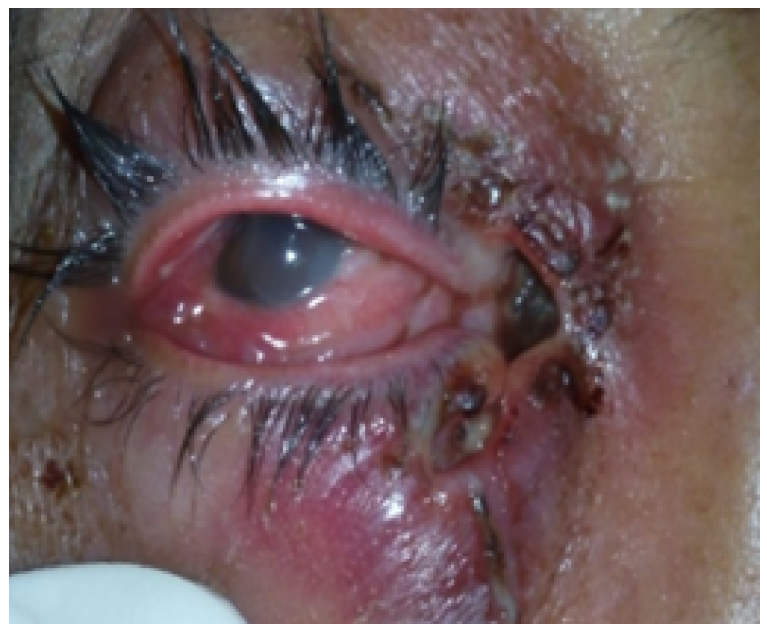

Figure 2 Lesion at the medial canthus, with free-moving maggots.
A total of 26 maggots were removed. The maggots were preserved in $10 \%$ formalin and sent for entomological evaluation to the Department of Microbiology. The larvae were creamy white in color, with cuticular spines, and varied in size due to different stages of presentation, from 5 to $15 \mathrm{~mm}$. They had strong robust mouth hooks, with four to six papillae on the anterior spiracles, incomplete posterior spiracular peritreme, and pigmented dorsal tracheal trunks in the terminal twelfth larval segment. Based upon these findings they were confirmed to be larvae of C. bezziana (Figures 6-8).

\section{Discussion}

Ophthalmomyiasis is mainly manifested as orbital myiasis, ophthalmomyiasis externa (external ocular structure), and ophthalmomyiasis interna (internal ocular structures). ${ }^{5,6}$ Ophthalmomyiasis externa is characterized by superficial infestation of the ocular tissue and mimics allergic or viral conjunctivitis. Patients complain of pain, burning, itching, redness, and watering in the affected eye, with an abrupt onset, accompanied by sensations of larvae moving in the eye. If timely management is not done, the larvae penetrate the sclera and reach the vitreous and subretinal space, causing ophthalmomyiasis interna as a complication. This manifests as pigmented and atrophic retinal pigment epithelial tracts in multiple crisscross patterns, in conjunction with fibrovascular proliferation, hemorrhage, and exudative detachment of the retina leading to blindness. Maggots can also infiltrate the lacrimal sac and can migrate through the lacrimal canal to the nasal cavity. Extension to the cranial cavity is a possibility, due to the close proximity to the base of the skull.

Normally, healthy individuals are unlikely to suffer from myiasis. ${ }^{7}$ Chronic debilitating conditions, such as leprosy, diabetes mellitus, open wounds, fungating carcinomas, psychiatric illness, intellectual disability, hemiplegia, and 


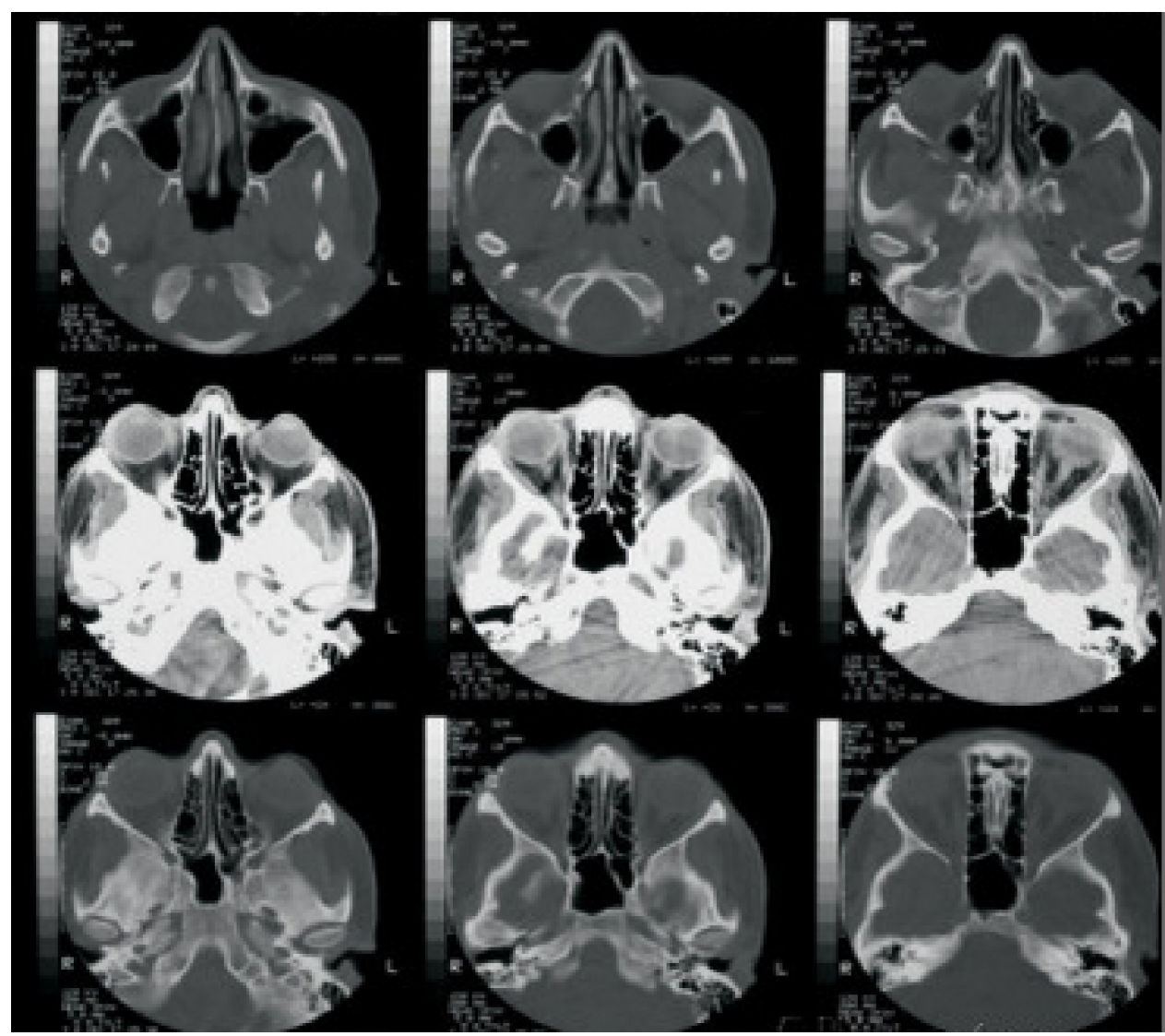

Figure $3 \mathrm{CT}$ scan orbit showing no signs of bone involvement, with normal sinuses. Abbreviation: $\mathrm{CT}$, computed tomography.

immunosuppressive agents may predispose individuals to myiasis. Infestation with $C$. bezziana differs from usual maggot infestations because it can invade tissue without preexisting necrotic tissue and cause extensive damage to living tissue if the condition is left undiagnosed. It buries itself deep in the tissue, causes necrosis, and remains firmly attached to it with help of its cuticular spines. The main

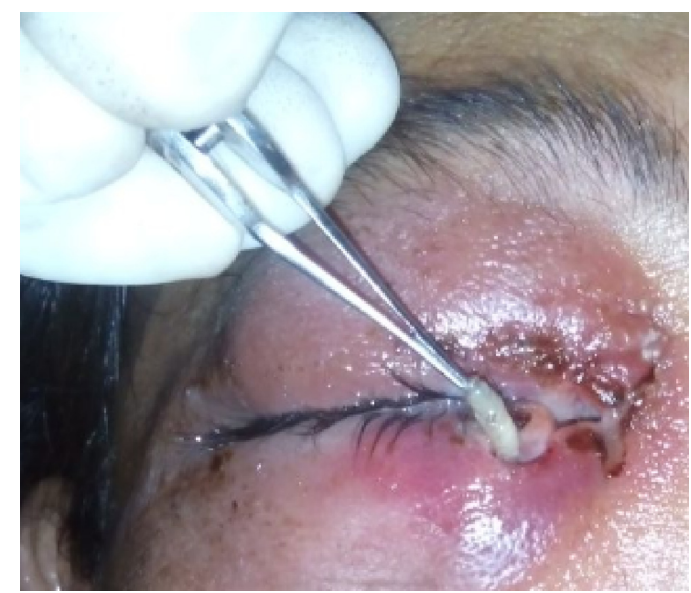

Figure 4 Mechanical removal of maggots with wound debridement. predisposing factors for the larval infestation in our patient were probably poverty and poor hygiene.

There are 12 species in the genus Chrysomya, most of which are known to cause myiasis in animals. In the literature, only C. bezziana and Cochliomyia hominivorax have been implicated in causing ophthalmomyiasis in living humans. ${ }^{8}$ The adult fly of Chrysomya is green or blue-green in color

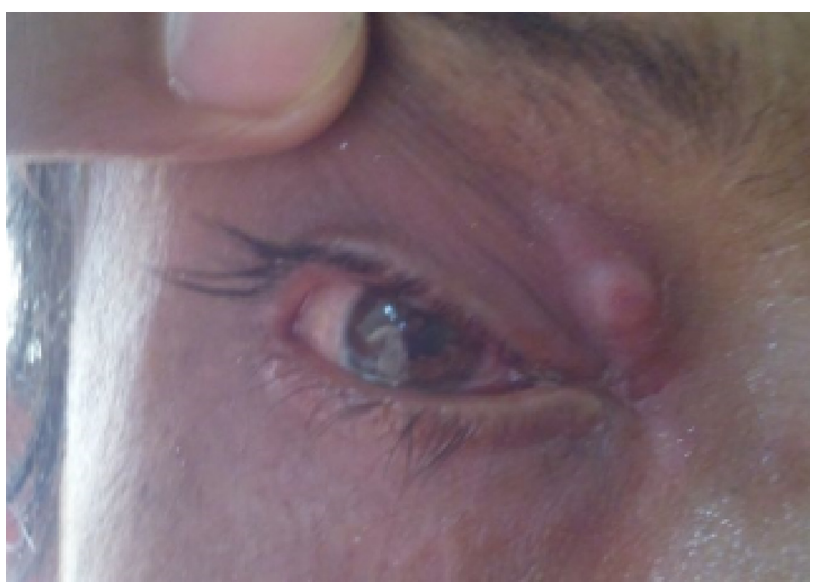

Figure 5 Follow up at 2 weeks, with completely healed wound. 


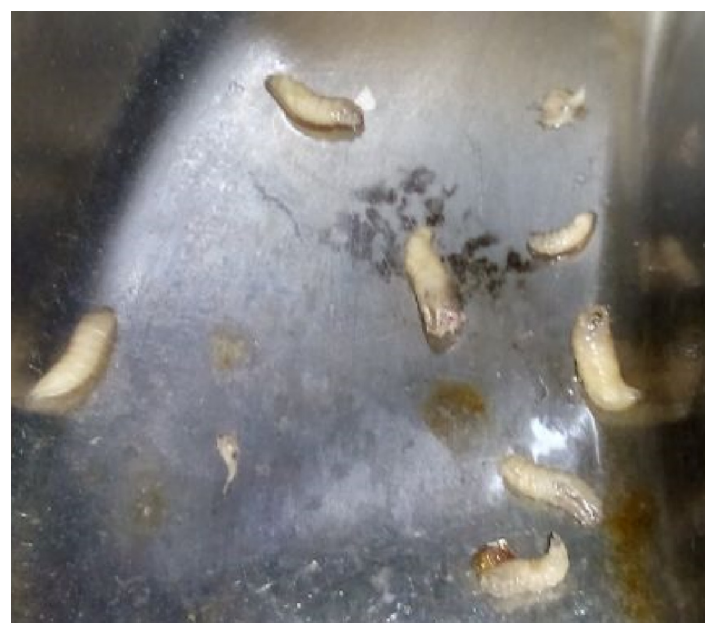

Figure 6 Maggots removed from patient's wound.

and feeds on decaying matter, excreta, and flowers. Approximately 150-200 eggs at a time are laid by the female adult, on exposed wounds and mucous membranes of the mouth, ears, and nose. After 24 hours, eggs hatch, and larvae burrow deep into the living tissue in a screwlike fashion, completing their development while feeding on host tissue for 5-7 days. Thereafter they fall to the ground to pupate. The pupal stage is temperature-dependent, with sexual maturation in approximately 1 week to 2 months. Thus it takes $2-3$ months to complete their life cycle. ${ }^{9}$

C. bezziana has been implicated in cancer-associated myiasis of skin, larynx, face, and breast. ${ }^{10-12}$ Its involvement in oral myiasis was recorded as early as 1946, in India. ${ }^{13}$ In a recent report from Iran, C. bezziana larvae caused oral myiasis in an 18-year-old boy with congenital cerebral palsy, quadriplegia, and intellectual disability. It has also been reported as the agent causing urogenital myiasis and otomyiasis. A case of cutaneous myiasis caused by C. bezziana larvae, in


Figure 7 Mouth hooks with cuticular spines around body of larvae.

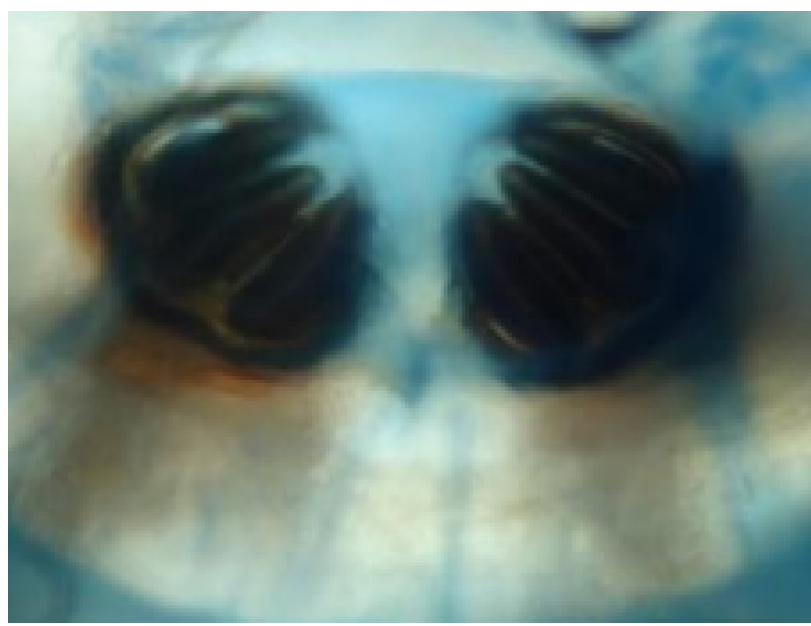

Figure 8 Incomplete posterior spiracular peritreme of Chrysomya bezziana.

a 62-year-old woman who had a complex vascular cutaneous anomaly in her lower right extremity for 8 years, was reported from Mexico in 2010. ${ }^{14}$

Various methods for removal of the maggots have been documented. The basic principle involves either suffocating the larvae and forcing them out or first paralyzing them followed with mechanical debridement as shown in Table 1. ${ }^{15-20}$ Systemic treatment with broad-spectrum antibiotics, such as amoxicillin with clavulanic acid, metronidazole, and cefazolin are indicated to prevent secondary bacterial infections. ${ }^{21}$ Antiparasitic drugs such as ivermectin, a semisynthetic macrocyclic lactone, can be used in cases of advanced orbital myiasis, in a dose of $200 \mu \mathrm{g} / \mathrm{kg} .{ }^{22}$ Ivermectin blocks the nerve impulses through the release of gamma aminobutyric acid (GABA), resulting in palsy and death of larvae. ${ }^{23}$

Successful treatment of myiasis depends upon the stage of presentation, severity, and associated predisposing conditions.

Table I Agents used in treatment of myiasis

\begin{tabular}{ll}
\hline Agents used for & Liquid paraffin \\
suffocating the larvae & Petroleum jelly \\
& Bee wax \\
& Resins \\
& Glue \\
& Adhesive tape \\
& Nail polish \\
& Chewing gum \\
& Pork fat \\
& Vaseline \\
& Polymyxin B sulfate ointment \\
& Chloroform \\
Agents used for & Ether \\
paralyzing the larvae & I\% lidocaine \\
& Pilocarpine \\
\hline
\end{tabular}




\section{Conclusion}

Ophthalmomyiasis is an uncommon condition but becomes significant in debilitated and compromised patients. Measures such as general cleanliness of surroundings, maintaining good personal hygiene, provision of basic sanitation, and health education have to be stressed, for preventing myiasis.

\section{Acknowledgment}

We thank the Department of Microbiology, Assam Medical College for helping us in identification of the larvae and providing photographs of the same.

\section{Disclosure}

The authors report no conflicts of interest in this work.

\section{References}

1. Sivaramasubramanyam P, Sadanand AV. Ophthalmomyiasis. $\mathrm{Br} J$ Ophthalmol. 1968;52(1):64.

2. Burns DA. Diseases caused by arthropods and other noxious animals. In: Rook's Textbook of Dermatology. Vol 2. Oxford, UK: Blackwell Science, 11th ed. 2012:33.1-33.63.

3. Lagacé-Wiens PR, Dookeran R, Skinner S, Leicht R, Colwell DD, Galloway TD. Human ophthalmomyiasis interna caused by Hypoderma tarandi, Northern Canada. Emerg Infect Dis. 2008;14(1):64-66.

4. Sutherst RW, Spradbery JP, Maywald GF. The potential geographical distribution of the Old World screw-worm fly, Chrysomya bezziana. Med Vet Entomol. 1989;3(3):273-280.

5. Khataminia G, Aghajanzadeh R, Vazirianzadeh B, Rahdar M. Orbital myiasis. J Ophthalmic Vis Res. 2011;6(3):199-203.

6. Sigauke E, Beebe WE, Gander RM, Cavuoti D, Southern PM. Case report: ophthalmomyiasis externa in Dallas County, Texas. Am J Trop Med Hyg. 2003;68(1):46-47.

7. Duke-Elder S, editor. System of Ophthalmology. Vol 1. St Louis, MO: Mosby; 1958.
8. Khurana S, Biswal M, Bhatti H. Ophthalmomyiasis: Three cases from North India. Indian J Med Microbiol. 2010;28(3):257-261.

9. Walker AR. The Arthropods of Human and Domestic Animals. A Guide to Preliminary Identification. London: Chapman \& Hall; 1994.

10. Hawayek LH, Mutasim DF. Myiasis in a giant squamous cell carcinoma. J Am Acad Dermatol. 2006;54(4):740-741.

11. Rubio C, Ladrón de Guevara C, Martín MA, Campos L, Quesada A, Casado M. [Cutaneous myiasis over tumor-lesions: presentation of three cases]. Actas Dermosifiliogr. 2006;97(1):39-42. Spanish.

12. Kwong A, Yiu WK, Chow LW, Wong S. Chrysomya bezziana: a rare infestation of the breast. Breast J. 2007;13(3):297-301.

13. Grennan S. A case of oral myiasis. Br Dent J. 1946;80:274.

14. Romero-Cabello R, Calderón-Romero L, Sánchez-Vega JT, Tay J, Romero-Feregrino R. Cutaneous myiasis caused by Chrysomya bezziana larvae, Mexico. Emerg Infect Dis. 2010;16(12):2014-2015.

15. Ashenhurst M, Pietucha S. Management of ophthalmomyiasis externa: case report. Can J Ophthalmol. 2004;39(3):285-287.

16. Swetter SM, Stewart MI, Smoller BR. Cutaneous myiasis following travel to Belize. Int J Dermatol. 1996;35(2):118-120.

17. De Tarso P, Pierre-Filho P, Minguini N, Pierre LM, Pierre AM. Use of ivermectin in the treatment of orbital myiasis caused by Cochliomyia hominivorax. Scand J Infect Dis. 2004;36(6-7):503-505.

18. Richards KA, Brieva J. Myiasis in a pregnant woman and an effective, sterile method of surgical extraction. Dermatol Surg. 2000;26(10): 955-957.

19. Brewer TF, Wilson ME, Gonzalez E, Felsenstein D. Bacon therapy and furuncular myiasis. JAMA. 1993;270(17):2087-2088.

20. Mandell GL, Bennett JE, Dolin R. Infectious diseases and their etiologic agents. In: Principles and Practice of Infectious Diseases. Vol 2. 5 ed. Philadelphia, PA: Churchill Livingstone; 2000:2976-2979.

21. Asokan GS, Anand V, Balaji N, Parthiban J, Jeelani S. Maggots in the mouth-oral myiasis: a rare case report. J Indian Aca Oral Med Radiol. 2013;25(3):225-228.

22. Campbell WC. Ivermectin: an update. Parasitol Today. 1985;1(1): $10-16$.

23. Osorio J, Moncada L, Molano A, Valderrama S, Gualtero S, FrancoParedes C. Role of ivermectin in the treatment of severe orbital myiasis due to Cochliomyia hominivorax. Clin Infect Dis. 2006;43(6): e57-e59.
Clinical Ophthalmology

\section{Publish your work in this journal}

Clinical Ophthalmology is an international, peer-reviewed journa covering all subspecialties within ophthalmology. Key topics include: Optometry; Visual science; Pharmacology and drug therapy in eye diseases; Basic Sciences; Primary and Secondary eye care; Patient Safety and Quality of Care Improvements. This journal is indexed on

Submit your manuscript here: http://www.dovepress.com/clinical-ophthalmology-journal

\section{Dovepress}

PubMed Central and CAS, and is the official journal of The Society of Clinical Ophthalmology (SCO). The manuscript management system is completely online and includes a very quick and fair peer-review system, which is all easy to use. Visit http://www.dovepress.com/ testimonials.php to read real quotes from published authors. 